\title{
Long-term follow-up of sepsis induced immunoparalysis
}

\author{
M Raja ${ }^{1 *}$, HDT Torrance ${ }^{1,2}$, ER Longbottom ${ }^{1,2}$, AJ Stroud ${ }^{1}$, ME Vivian ${ }^{1}$, PS Zolfaghari ${ }^{1}$, RM Pearse ${ }^{1,2}$, CJ Hinds ${ }^{1,2}$, \\ MJ O'Dwyer ${ }^{1,2}$
}

From ESICM LIVES 2015

Berlin, Germany. 3-7 October 2015

\section{Introduction}

Severe sepsis induces a state of immunoparalysis.[1] Animal models have demonstrated this to be secondary to microbial-induced host epigenetic alterations, which persist and are associated with long-term immunoparalysis.[2] Whilst human sepsis is associated with poor long-term outcomes in conjunction with recurrent infections,[3] it is not clear if the immunoparalysed state persists following recovery from the initial septic insult.

\section{Objectives}

1. To confirm the presence of circulating mediators capable of causing immunoparalysis following bacteraemia.

2. To assess for the presence of immunosuppressive mediators following hospital discharge with full functional recovery.

\section{Methods}

Consecutive adult patients $(\mathrm{n}=7)$ with bacteraemia and an admission diagnosis of infection were recruited. Serum was collected at 3 time points; within 48 hours of the positive blood culture, 5 days later \& 12 months following hospital discharge. Peripheral blood mononuclear cells (PBMCs) were collected from a healthy control cohort $(\mathrm{n}=7)$ and pooled. Healthy PBMCs were co-cultured with $30 \%$ septic serum for 20 hours with and without GM-CSF (200ng/ml). CD14 ${ }^{+}$HLA-DR (mHLA-DR) geometric-mean fluorescent intensity (MFI) was determined using flow cytometry. Data were analysed with non-parametric statistics with results presented as median \& IQR .

\section{Results}

Three patients required ICU care \& four were managed on the ward. Demographic \& clinical data are presented in Figure 2. mHLA-DR levels were lower when PBMCs were co-cultured with the baseline bacteraemic sample in comparison with control group serum (Figure $1, P=0.01$ ). mHLA-DR levels following co-culture with the baseline sample were not significantly different to the levels observed when co-cultured with day 5 serum (Figure 1A). In comparison to the baseline sample, when co-cultured with serum from 12 months, mHLA-DR levels were increased (Figure 1A, $P=0.007$ ). mHLA-DR levels at 12 months were not different from those seen when control serum was used (Figure $1 \mathrm{AP}=0.85$ ). mHLA-DR levels were higher in the presence of GM-CSF when co-cultured with baseline (Figure $1 \mathrm{~B}, P=0.01$ ) and 12 month (Figure $1 \mathrm{~B}, P=0.02$ ) samples but not with day 5 serum (Figure $1 \mathrm{~B}, P=0.17$ ).

\section{Conclusions}

Circulating mediators present in the serum of bacteraemic patients reduces the ability of healthy monocytes to express cell surface HLA-DR, which is reversible in the presence of an immunostimulant. Serum from patients following full recovery from the acute illness does not reduce HLA-DR expression on healthy monocytes.

\section{Grant Acknowledgment}

ESICM Basic Science Award 2014. 


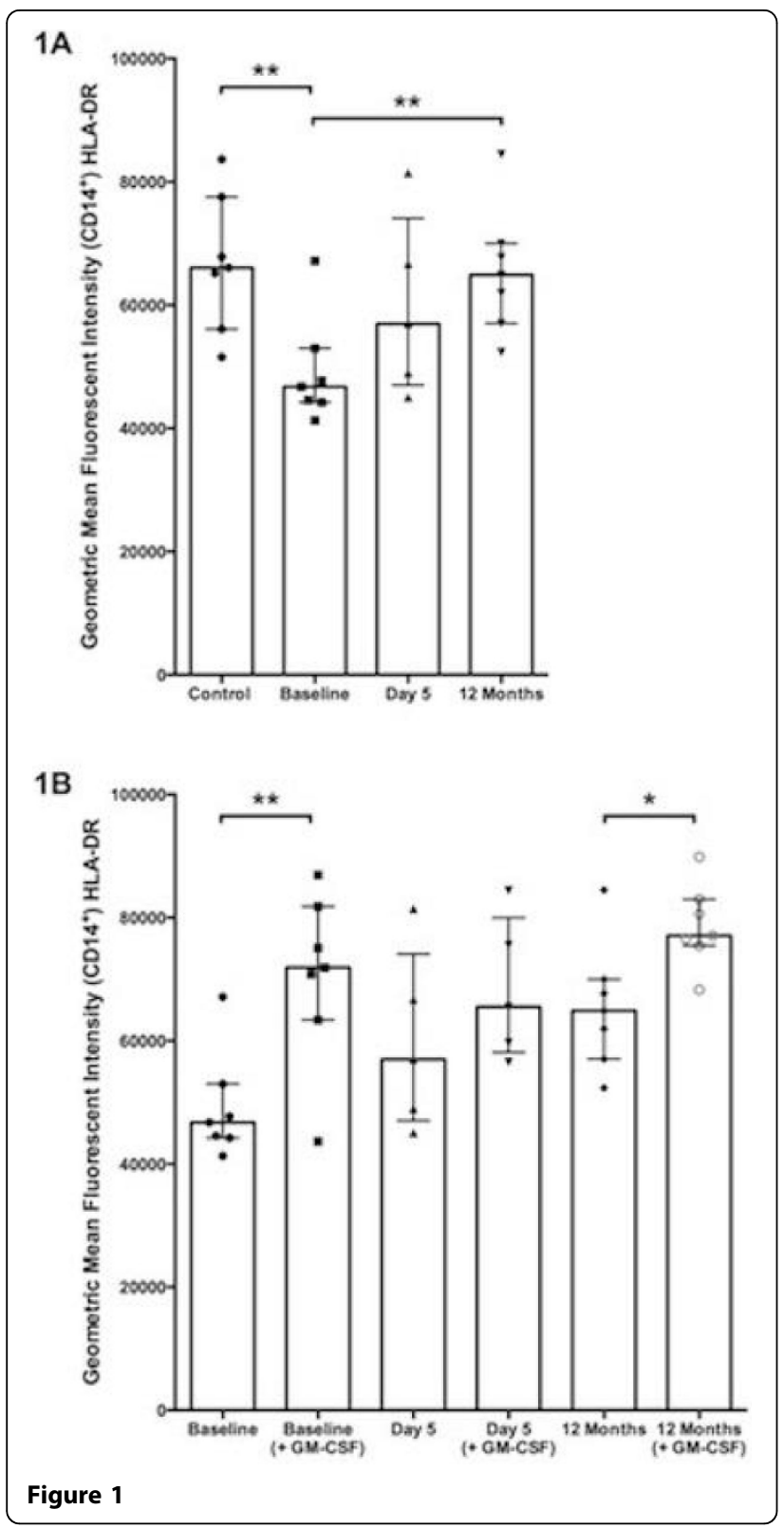

\begin{tabular}{|c|c|c|c|}
\hline & Severe Sepsis (n=3) & No Organ impairment $(n=4)$ & $P$ value \\
\hline Age & $71(60-88)$ & $45(31-58)$ & Ns \\
\hline Male $\mathrm{n}(\%)$ & $1(33.3)$ & $2(50)$ & Ns \\
\hline Hospital toS & $37(27-125)$ & $25(6-43)$ & Ns \\
\hline SOFA score on recruitment & $5(4.5 \cdot 8)$ & 0 & - \\
\hline Gram-ve (\%) & $2(66.6)$ & $2(50)$ & Ns \\
\hline Shocked during ICU stay & $1(33.3)$ & 0 & - \\
\hline
\end{tabular}

Figure 2 Demographic and clinical details of patients requiring ICU care (severe sepsis) and those receiving ward based care (no organ impairment).
Published: 1 October 2015

\section{References}

1. Deng JC, et al: Sepsis-induced suppression of lung innate immunity is mediated by IRAK-M. J Clin Invest 2006, 116:2532-42.

2. Carson WF, et al: Epigenetic regulation of immune cell functions during post-septic immunosuppression. Epigenetics 2011, 6:273-83.

3. Czaja AS, et al: Readmission and late mortality after paediatric severe sepsis. Paediatrics 2009, 123:849.

doi:10.1186/2197-425X-3-S1-A49

Cite this article as: Raja et al:: Long-term follow-up of sepsis induced immunoparalysis. Intensive Care Medicine Experimental 2015 3(Suppl 1):A49.

\section{Submit your manuscript to a SpringerOpen ${ }^{\mathcal{D}}$ journal and benefit from:}

- Convenient online submission

- Rigorous peer review

- Immediate publication on acceptance

- Open access: articles freely available online

- High visibility within the field

- Retaining the copyright to your article

Submit your next manuscript at $\boldsymbol{s p r i n g e r o p e n . c o m ~}$ 